\title{
Cultural and psychological factors of Vietnam's COVID-19 response
}

\author{
Ho Manh Tung \\ Ritsumeikan Asia Pacific University \\ Верpu, Oita, Japan \\ January 10, 2021
}

Scholars have been struggling to provide a comprehensive account of the success of Vietnam's COVID-19 response. The early analyses focus on historical, political, and technical attributes such as the nation's experience with SARS-COV-1 back in the early 2000s, the intense public messaging around SARS-COV-2, the aggressive contact-tracing, the advantage of its own political structure, the early and decisive actions from the government, etc. $[1,2,3,4]$. In the more recent analyses, scholars have started to delve into cultural and sociological factors. For example, Adam Fforde argues the influence of social media has outweighed the influence of the Marxist ideology, which explains the success of Vietnam's COVID-19 response in the paper title "Vietnam and COVID-19: More Mark (Zuckerberg) than Marx" [5]. However, these accounts fail to take into account the cultural and psychological factors that are deep-seated in the Vietnamese psyche. Here, I would like to recap the factors that are overlooked in the mainstream discussion.

1. In a recent publication, two NYU researchers [6] argue the mixing of cultural values, i.e., the cultural additivity from Tam Giao (Three Teachings - Confucianism, Taoism, Buddhism) $[7,8,9]$ provides "a unique mindset that other countries can learn from to adapt and even build psychological resilience against COVID-19 pandemic's psychological outcomes." The cultural additivity phenomenon underlies the harmonizing of even contradictory value, 
which then underlies the mindset of Vietnam in combating the denial of the seriousness of the pandemic, in embracing the community policing and enforcing of quarantine rules, argued Small and Blanc [6].

2. The traditional way of living is still very entrenched in urban living in Vietnam. People in Vietnam have not become an atomized, individualized units. Rather a majority still either lives with their extended family or frequently visits their families. Such a social structure raises the stake for people in two ways. The first is that people know if they are infected, many more people they really care about can be infected. Secondly, when everyone is so embedded in a large social network of friends and families, the psychological cost of isolation when getting infected also increases.

3. Vivid accounts of people's travel histories make the risk of infection more visceral, making it easier to mobilize people to take precautions. A basic fact of human psychology is vivid personal accounts move other people better than statistics. Vietnam is still at the stage when the number of people infected each day is small enough that the vivid traveling and contacting accounts can be posted on the government's social media channel. These accounts include dozens of places a positive case visited, which signify a very high risk of infection and induce visceral reactions to the risk: "I had lunch at that restaurant on Thursday, had it been one day later, I would have been at risk of being infected." In countries like the US and Japan, the number of cases is thousands each day. Such an abstract number is large and tragic, undoubtedly, but when it comes to appealing to people's intuition, they fall short.

4. There is also a lack of focus on the biopolitical nature [10, 11] of Vietnam's COVID19 response. Historically, Vietnam has been successful with the population's biopolitical control: 
the family planning, the wearing of helmets when driving a motorbike, for example. Thus, the COVID-19 response can be seen as an extension of biopolitics' historical success in Vietnam.

In the space of a short essay, it is hard to exhaust the list of plausible sociological, psychological, and cultural factors that contribute to Vietnam's COVID-19 response's collective success. Further studies that draw on Vietnamese society's cultural and psychological studies $[12,13,14,15]$ are needed to create the most comprehensive account of the Vietnamese experience with the global pandemic.

\section{References}

1. La V-P, Pham T-H, Ho M-T, et al. Policy Response, Social Media and Science Journalism for the Sustainability of the Public Health System Amid the COVID-19 Outbreak: The Vietnam Lessons. Sustainability. 2020; 12.

2. Nguyen, N. P. T., Hoang, T. D., Tran, V. T., Vu, C. T., Siewe Fodjo, J. N., Colebunders, R., . . . Vo, T. V. (2020). Preventive behavior of Vietnamese people in response to the COVID19 pandemic. PLOS ONE, 15(9), e0238830. doi:10.1371/journal.pone.0238830

3. Nguyen, N. P. T., Hoang, T. D., Tran, V. T., Vu, C. T., Siewe Fodjo, J. N., Colebunders, R., . . . Vo, T. V. (2020). Preventive behavior of Vietnamese people in response to the COVID19 pandemic. PLOS ONE, 15(9), e0238830. doi:10.1371/journal.pone.0238830

4. Nguyen, T.-H.-K., \& Ho, M.-T. (2020). Vietnam's COVID-19 Strategy: Mobilizing Public Compliance Via Accurate and Credible Communications. ISEAS Perspective, 69(2020). Retrieved

from https://www.iseas.edu.sg/wpcontent/uploads/2020/05/ISEAS_Perspective_2020_69.pdf 
5. Fforde, A. (2020). Vietnam and COVID-19: More Mark (Zuckerberg) than Marx. Melbourne Asia Review. Retrieved from https://melbourneasiareview.edu.au/vietnam-and-covid-19more-mark-zuckerberg-than-marx/

6. Small, S., \& Blanc, J. (2021). Mental Health During COVID-19: Tam Giao and Vietnam's Response. Frontiers in Psychiatry, 11(1507). doi:10.3389/fpsyt.2020.589618

7. Vuong, Q.-H., Bui, Q.-K., La, V.-P., et al. (2018). Cultural additivity: Behavioural insights from the interaction of Confucianism, Buddhism and Taoism in folktales. Palgrave Communications, 4(1), 143. doi:10.1057/s41599-018-0189-24.

8. Vuong, Q.-H., Ho, M.-T., Nguyen, H.-K. T., et al. (2020). On how religions could accidentally incite lies and violence: folktales as a cultural transmitter. Palgrave Communications, 6(1), 82. doi:10.1057/s41599-020-0442-3

9. Vuong, Q.-H., Bui, Q.-K., La, V.-P., et al. (2019). Cultural evolution in Vietnam's early 20th century: A Bayesian networks analysis of Hanoi Franco-Chinese house designs. Social $\begin{array}{lllll}\text { Sciences } \quad \& \quad \text { Humanities } & \text { Open, } & 1(1), & 100001 .\end{array}$ doi:https://doi.org/10.1016/j.ssaho.2019.100001

10. Lemke, T. (2011). Biopolitics: An advanced introduction (Vol. 5). New York: NYU Press.

11. Foucault, M. (2019). Power: the essential works of Michel Foucault 1954-1984. London: Penguin UK.

12. Vuong, Q. H. (2016). Global mindset as the integration of emerging socio-cultural values through mindsponge processes: A transition economy perspective. In: J. Kuada (ed.) Global Mindsets: Exploration and Perspectives (pp. 109-126). London: Routledge. 
13. Vuong, Q. H., Napier, N. K. (2015). Acculturation and global mindsponge: an emerging market perspective. International Journal of Intercultural Relations, 49, 354-67.

14. Hoang, V. Q., \& Dung, T. T. (2009). The Cultural Dimensions of the Vietnamese Private Entrepreneurship. IUP Journal of Entrepreneurship Development, 6(3/4), 54-78.

15. Phạm Minh Chính, Vương Quân Hoàng. (2009). Kinh tế Việt Nam: Thăng trầm và đột phá. Nxb Chính trị Quốc gia, Hà Nội. 